Atmos. Chem. Phys., 10, 8499-8510, 2010

www.atmos-chem-phys.net/10/8499/2010/

doi:10.5194/acp-10-8499-2010

(C) Author(s) 2010. CC Attribution 3.0 License.

\title{
A closer look at Arctic ozone loss and polar stratospheric clouds
}

\author{
N. R. P. Harris ${ }^{1}$, R. Lehmann ${ }^{2}$, M. Rex ${ }^{2}$, and P. von der Gathen ${ }^{2}$ \\ ${ }^{1}$ European Ozone Research Coordinating Unit, Department of Chemistry, University of Cambridge, Lensfield Rd, \\ Cambridge, CB2 1HE, UK \\ ${ }^{2}$ Alfred Wegener Institute, Potsdam, Germany
}

Received: 24 December 2009 - Published in Atmos. Chem. Phys. Discuss.: 10 March 2010

Revised: 2 August 2010 - Accepted: 31 August 2010 - Published: 8 September 2010

\begin{abstract}
The empirical relationship found between column-integrated Arctic ozone loss and the potential volume of polar stratospheric clouds inferred from meteorological analyses is recalculated in a self-consistent manner using the ERA Interim reanalyses. The relationship is found to hold at different altitudes as well as in the column. The use of a PSC formation threshold based on temperature dependent cold aerosol formation makes little difference to the original, empirical relationship. Analysis of the photochemistry leading to the ozone loss shows that activation is limited by the photolysis of nitric acid. This step produces nitrogen dioxide which is converted to chlorine nitrate which in turn reacts with hydrogen chloride on any polar stratospheric clouds to form active chlorine. The rate-limiting step is the photolysis of nitric acid: this occurs at the same rate every year and so the interannual variation in the ozone loss is caused by the extent and persistence of the polar stratospheric clouds. In early spring the ozone loss rate increases as the solar insolation increases the photolysis of the chlorine monoxide dimer in the near ultraviolet. However the length of the ozone loss period is determined by the photolysis of nitric acid which also occurs in the near ultraviolet. As a result of these compensating effects, the amount of the ozone loss is principally limited by the extent of original activation rather than its timing. In addition a number of factors, including the vertical changes in pressure and total inorganic chlorine as well as denitrification and renitrification, offset each other. As a result the extent of original activation is the most important factor influencing ozone loss. These results indicate that relatively simple parameterisations of Arctic ozone loss could be developed for use in coupled chemistry climate models.
\end{abstract}

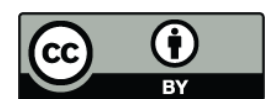

Correspondence to: N. R. P. Harris (neil.harris@ozone-sec.ch.cam.ac.uk)

\section{Introduction}

Polar ozone loss has been the subject of intense scientific and public interest since the discovery of the Antarctic ozone hole (Farman et al., 1985) and its relatively quick attribution to observations of chlorine compounds (de Zafra et al., 1987; Solomon et al., 1987; Anderson et al., 1989). Stratospheric ozone loss takes place in the polar vortex which forms over each pole in their respective winters. Marked differences in stratospheric dynamics in the two hemispheres naturally lead to large interannual variations in vortex stability and in ozone in the dynamically active Arctic winter stratosphere and to small interannual variations in the dynamically less active Antarctic. These differences lead to higher natural average amounts of total ozone over the Arctic ( $\sim 450$ Dobson Units - DU) than over the Antarctic ( 300 DU - Dobson, 1968; Newman and Rex, 2007). These differences in dynamics also lead to a much greater variability of polar ozone loss over the Arctic (where, for example, there were losses of $<10 \%$ in 1998/1999 (Schulz et al., 2001) and $>65 \%$ in 1999/2000 (Rex et al., 2002) at around $18 \mathrm{~km}$ ) than over the Antarctic where nearly complete ozone loss has taken place in nearly all winters since the early 1990s at altitudes between about 15 and $20 \mathrm{~km}$. Even in the anomalous year of 2002 when the Antarctic vortex was disturbed and broke up just after the middle of September, the minimum daily total ozone value south of $40^{\circ} \mathrm{S}$ was $\sim 140 \mathrm{DU}, 30 \%$ below the late July values (Bodeker et al., 2005), and losses of 70-75\% had occurred between the 400 and $500 \mathrm{~K}$ isentropic surfaces (Hoppel et al., 2003; Ricaud et al., 2005). In percentage terms this loss is comparable with the largest losses observed in the Arctic.

This large variability in the Arctic dynamics coupled with a number of microphysical and photochemical thresholds has made it hard to reproduce ozone loss in past winters for which the meteorology is known and analyses are

Published by Copernicus Publications on behalf of the European Geosciences Union. 
available, although 3-D chemical transport models (CTMs - e.g., Chipperfield et al., 2005) and data assimilation approaches (Jackson and Orsolini, 2008) have been continually improving. However the additional complication of calculating the stratospheric dynamics (coupled with the sensitivity of the ozone loss processes to the dynamics and transport) means that it is even harder to predict Arctic ozone losses for the coming decades using coupled chemistry climate models (CCMs) (Austin et al., 2003; Eyring et al., 2007). The sensitivity of ozone loss to changes in climate is thus hard to assess.

The basic mechanisms leading to ozone loss are the same over the two poles and are generally well understood (e.g., Newman and Rex, 2007). As the polar vortex is established, the temperatures drop below a critical point, and polar stratospheric clouds (PSCs) can form. $\mathrm{HCl}$ and $\mathrm{ClONO}_{2}$ react on the surface of PSCs, with these unreactive chlorine species being converted under sunlit conditions to active forms $\left(\mathrm{ClO}_{\mathrm{x}}=\mathrm{ClO}+2 \cdot \mathrm{Cl}_{2} \mathrm{O}_{2}\right)$ which can rapidly destroy ozone. In the absence of further exposure to PSCs, the $\mathrm{ClO}$ (chlorine monoxide) formed continues to destroy ozone while it is gradually converted back to unreactive forms. The observed evolution of the main chemical species in the Arctic can be seen in Fig. 1 for the 2004/2005 winter. The concentrations of $\mathrm{HCl}$ and $\mathrm{ClONO}_{2}$ decrease in the presence of PSCs, while the inferred concentration of $\mathrm{ClO}_{\mathrm{x}}$ increases. (Note that $\mathrm{ClO}_{\mathrm{x}}$ in Fig. 1 is calculated as $\mathrm{Cl}_{\mathrm{y}}$ minus $\mathrm{ClONO}_{2}$ and $\mathrm{HCl}$ so it includes minor species such as $\mathrm{HOCl}$ and $\mathrm{Cl}_{2}$.) Continued PSC occurrence leads to continued formation of $\mathrm{ClO}_{\mathrm{x}}$ until the $\mathrm{HCl}$ is low. Reversion of $\mathrm{ClO}_{\mathrm{x}}$ to $\mathrm{ClONO}_{2}$ and $\mathrm{HCl}$ occurs as the vortex warms and the PSCs evaporate. Occasionally in Arctic winters, particularly large ozone losses can occur when air masses become depleted in $\mathrm{HNO}_{3}$ as PSCs sediment to lower altitudes during prolonged cold periods, a process that delays the deactivation of the active chlorine species. The persistence of PSCs depends very strongly on the dynamical situation in that winter and so is the main reason that ozone loss can vary so much from year to year in the Arctic.

Given the mechanistic complexity and large variability, it came as a surprise to find that a compact, linear relation exists between ozone loss and the calculated volume of PSCs $\left(V_{\mathrm{PSC}}\right)$ when each is integrated over the period of vortex existence (Rex et al., 2004, 2006). The relation holds over a wide range of ozone losses and PSC volumes implying that the effects of many influences on ozone loss (e.g., denitrification, solar exposure, initial chemical fields, descent rates, inmixing, vortex inhomogeneities, and vertical extent) must be offsetting to some extent. The existence of this relation (calculated from temperature fields and vortex average descent rates derived from meteorological analyses and ozonesonde measurements) has been confirmed using HALOE satellite measurements and an independent approach to calculating the ozone loss (Tilmes et al., 2004). Both Rex et al. (2004) and Tilmes et al. (2004) found larger than expected chemical

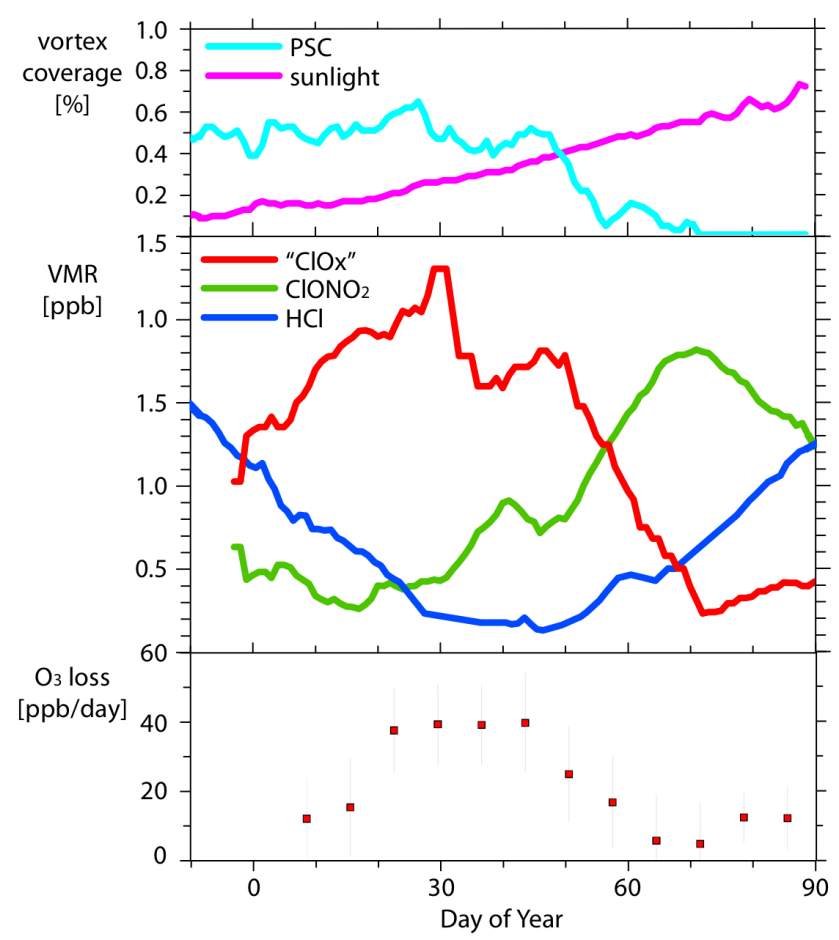

Fig. 1. Evolution of chlorine species inside the Arctic vortex at $460 \mathrm{~K}$ in the 2004/2005 winter. The top panel shows the area of PSCs as a percentage of the vortex area (light blue) and the vortex average sunlit time per day in percent (pink). PSCs are assumed to be NAT and the area is calculated from ECMWF analyses. A value of $36 \mathrm{~s}^{-1}$ normalized potential vorticity is used to define the edge of the vortex (see Rex et al., 1999). This value is close to the maximum horizontal gradient in normalized PV between early January and late March. The middle panel (based on Santee et al., 2008) is the vortex average $\mathrm{HCl}$ from Aura MLS, the vortex average $\mathrm{ClONO}_{2}$ from ACE FTS, and an estimate of the vortex average $\mathrm{ClO}_{\mathrm{x}}$ found by subtracting the sum of the $\mathrm{HCl}$ and $\mathrm{ClONO}_{2}$ from $2.8 \mathrm{ppb}$, a representative value of $\mathrm{Cl}_{\mathrm{y}}$ for $460 \mathrm{~K}$ in that winter. $\mathrm{ClONO}_{2}$ and $\mathrm{ClO}_{\mathrm{x}}$ have been smoothed with a 10 day running mean in order to compensate for the sampling biases from ACE FTS, which has the typical sampling issues of any solar occultation instrument. The bottom panel shows the ozone loss rates found from the Match campaign for that year (Rex et al., 2006).

ozone losses in the 1991/1992 and 1992/1993 winters which they attributed to the increase in stratospheric aerosol following the eruption of Mt Pinatubo.

Otherwise there has been little mechanistic investigation, and the explanation for the existence of the relation is not detailed, being simply that large ozone losses occur in cold winters when PSCs are widespread and long-lasting, while small ozone losses occur in warm winters when PSCs are less common. This explanation does not really address either the compactness or the near-linearity of the relation. The lack of explanation is one of the main reasons why it has not been used to evaluate the coupled climate models (CCMs) in the CCM Validation Activity for SPARC (CCMVal) (see Eyring 
et al., 2005, updated at http://www.pa.op.dlr.de/CCMVal/ CCMVal_EvaluationTable.html; SPARC CCMVal, 2010), despite its empirical robustness and the implication that there is a sensitivity of $15 \mathrm{DU}$ column ozone loss for each $1{ }^{\circ} \mathrm{C}$ cooling (Rex et al., 2006). The relation has however been used to evaluate (a) the improvements made to the SLIMCAT 3-D Chemical Transport Model (CTM) which previously showed a compact, linear relation of the wrong slope (Rex et al., 2004), and now can reproduce the slope as well (Chipperfield et al., 2005; Fig. 4.13 in Newman and Rex, 2007), and (b) the ozone loss calculated in the Whole Atmosphere Community Climate Model (WACCM) (Tilmes et al., 2007).

The aim of this paper is to explain the compactness and linearity of this relationship and to unravel the important factors already present in the models as well as in the atmosphere. We are not trying to reproduce the observed relation quantitatively - that has already been done in more sophisticated models. We therefore choose to use a relatively simple tool (a photochemical box model with idealized trajectories) to identify the main processes rather than a more complex model which is harder to diagnose. Our earlier work (Harris et al., 2009) found that the rate-determining step for chlorine activation is the photolysis of $\mathrm{HNO}_{3}$, while the subsequent ozone loss depended on the competition between the photolysis of $\mathrm{Cl}_{2} \mathrm{O}_{2}$ (leading to ozone loss) and $\mathrm{HNO}_{3}$ (leading to deactivation). Since both processes go faster as the solar zenith angle decreases, the integrated ozone loss depends primarily on the extent of the initial chlorine activation and not on the speed of the ozone loss. Here we investigate the empirical $V_{\mathrm{PSC}}$ /ozone loss relationship in more detail using ERA Interim reanalyses and looking at its altitude dependence, and we extend the photochemical analysis to investigate the effect of multiple activations, denitrification and the vertical distribution of available chlorine $\left(\mathrm{Cl}_{\mathrm{y}}\right)$.

In the next section the methodology and data sources are described. In Sect. 3, the altitude variation of the relation is investigated and the sensitivity to the assumptions about PSC composition are discussed. The critical photochemical steps involved in the activation and deactivation steps are then described and illustrated in Sect. 4 by photochemical calculations on a single surface. Three dimensional aspects are discussed in Sect. 5. Finally the relevance and context of these results is discussed and summarised in Sect. 6.

\section{Methodology}

This study uses the values for ozone loss and $V_{\mathrm{PSC}}$ calculated in Rex et al. (2006) updated with values for 2005/2006, 2006/2007 and 2007/2008 using the same methodology. Vortex averaged profiles of ozone loss have been determined as the differences between ozone mixing ratio profiles at the end of March and early January, with an adjustment for the vortex average descent being made using diabatic heating rates from the SLIMCAT CTM. These have been converted into concentration versus altitude profiles, using the vortex averaged temperature and pressure profiles from late March. The total column loss was calculated as the vertical integral of the loss profiles between 14 and $24 \mathrm{~km}$ in March. The lower limit of this range $(\sim 380 \mathrm{~K})$ is close to the bottom of the wellisolated part of the polar vortex. For most winters ozone loss at this level is small. Also, the effect of any chemical loss in the vertical region below $14 \mathrm{~km}$ on the total ozone column in the Arctic would be limited because of rapid exchange with mid latitude air. Formation of PSCs above the vertical range considered here is unlikely (Pitts et al., 2009), and consequently significant chemical loss of ozone is not expected to be seen in air masses at or above $24 \mathrm{~km}$ at the end of winter. (Note that in our analysis we are using end of winter altitudes as a reference and that airmasses have descended from higher altitudes.) The estimated uncertainty in the integrated ozone loss is $\sim 10-15$ DU (Rex et al., 2002), mainly due to uncertainties in the calculated cooling rates and the potential impact of mixing across the vortex edge.

PSCs are assumed to be nitric acid trihydrate (NAT), and $V_{\mathrm{PSC}}$ is calculated from the laboratory observations of Hanson and Mauersberger (1988), a water vapour mixing ratio of $\mathrm{H}_{2} \mathrm{O}=5 \mathrm{ppm}$, and an observed profile of $\mathrm{HNO}_{3}$ (see Rex et al., 2002 for more details and discussion of the methodology). In this paper temperatures from ECMWF ERA-Interim re-analyses are used in order to have a consistent vertical resolution and data quality across the whole period. The validity of this approach, particularly the assumptions made about the composition of PSCs, is discussed further in Sect. 3.

In order to investigate the underlying processes, the Alfred Wegener Institute (AWI) photochemical box model was used. This model contains 48 chemical species and 174 reactions. The formation of solid and liquid PSC particles is simulated according to Murray (1967), Hanson and Mauersberger (1988) and Carslaw et al. (1995). For the photolysis of $\mathrm{Cl}_{2} \mathrm{O}_{2}$, the absorption cross sections from Burkholder et al. (1990) are used, which are close to the values found in the most recent laboratory studies (Chen et al., 2009; Papanastasiou et al., 2009; von Hobe et al., 2009). All remaining information on rate constants is taken from the NASAJPL 2006 Evaluation (Sander et al., 2006). The overhead ozone needed for the calculation of photolysis frequencies is the average of all ozonesonde measurements made between January and March from 1992-2007 at Ny-Alesund $\left(79^{\circ} \mathrm{N}\right)$. The numerical integration is performed using the kinetic preprocessor KPP (Damian et al. 2000). Unless otherwise stated, the model is initialised with $\mathrm{HCl}=2.25 \mathrm{ppb}$, $\mathrm{ClONO}_{2}=0.75 \mathrm{ppb}$ (consistent with Fig. 1 ), $\mathrm{ClO}_{\mathrm{x}}=0 \mathrm{ppb}$, $\mathrm{HNO}_{3}=10 \mathrm{ppb}, \mathrm{NO}_{\mathrm{x}}=0, \mathrm{H}_{2} \mathrm{O}=3.5 \mathrm{ppm}, \mathrm{O}_{3}=3 \mathrm{ppm}$ and $\mathrm{Br}_{\mathrm{y}}=20 \mathrm{ppt}$.

The model is run on idealised trajectories which correspond approximately to the range of conditions on the surfaces on which the observed ozone loss is derived. Horizontally, the trajectory is designed to mimic air toward the 


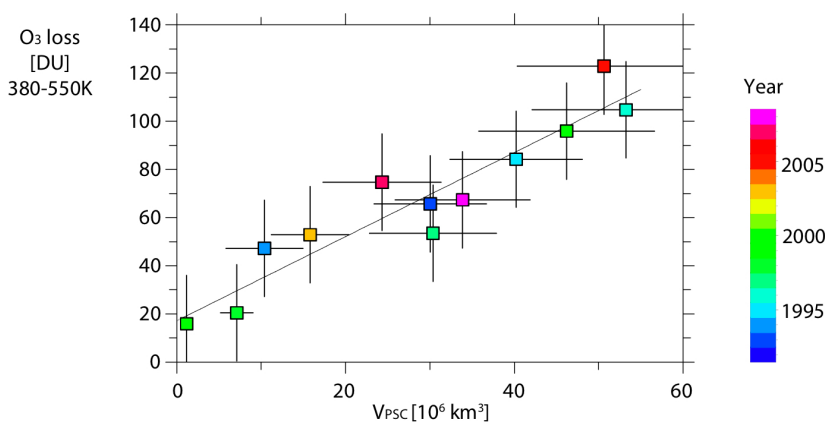

Fig. 2. Integrated ozone loss as a function of $V_{\mathrm{PSC}}$ for 1992/1993 to 2008/2009. Ozone losses are derived from the Arctic ozonesonde network using the vortex average approach. No meaningful ozone losses could be calculated in the winters 2000/2001, 2001/2002, 2003/2004, 2005/2006 and 2008/2009 due to major warmings overlapping with the ozone loss period and/or lack of ozonesonde data. The error bars associated with the ozone loss values reflect a conservative estimate of 20 DU (e.g. Newman and Rex, 2007). $V_{\mathrm{PSC}}$ is derived from ECMWF ERA-Interim re-analyses using the temperature of formation of nitric acid trihydrate. The error bars on $V_{\mathrm{PSC}}$ show the sensitivity to a temperature perturbation of $\pm 1 \mathrm{~K}$ in the ECMWF data. (Updated from Rex et al., 2006).

edge of an Arctic vortex which is centred at $80^{\circ} \mathrm{N}$ towards Europe with a radius corresponding to $20^{\circ}$ (as often encountered in reality). The airmass thus moves around the vortex with latitudes ranging from $60^{\circ} \mathrm{N}$ above Europe over the pole to $80^{\circ} \mathrm{N}$ above the Aleutians, taking 6 days to do so (a typical time for one circum-navigation). The main set of runs is performed at $50 \mathrm{hPa}(\sim 475 \mathrm{~K})$. Runs investigating the vertical dimension were performed at $550 \mathrm{~K}(\sim 30 \mathrm{hPa}), 500 \mathrm{~K}$ $(\sim 40 \mathrm{hPa})$ and $450 \mathrm{~K}(\sim 55 \mathrm{hPa})$. The analysis presented here is split into three main parts: the activation period (Sect. 4.1); the ozone loss period (Sect. 4.2); and aspects of the vertical dimension process (Sect. 5).

\section{Altitude variation of relation and PSC composition}

The original plots of integrated column ozone loss against integrated PSC volume (Rex et al., 2004, 2006) were calculated using ECMWF operational analyses. The PSC volumes shown in Fig. 2 are calculated using ERA-Interim re-analyses (Simmons et al., 2006). These give greater consistency between years. The general features of the plot are unchanged. The most notable change is that the largest value for $V_{\mathrm{PSC}}$ is now calculated to be in 1995/1996 rather than 2004/2005. The slope of a linear fit between ozone column loss and $V_{\text {PSC }}$ is slightly reduced. All these changes are within the estimate uncertainties.

Figure 3 shows the ozone loss on individual isentropic surfaces $(400,450,500$ and $550 \mathrm{~K})$ plotted against the area of PSCs $\left(A_{\mathrm{PSC}}\right)$, both integrated over the course of the winter. (As for the column ozone loss and $V_{\mathrm{PSC}}$, the isen-

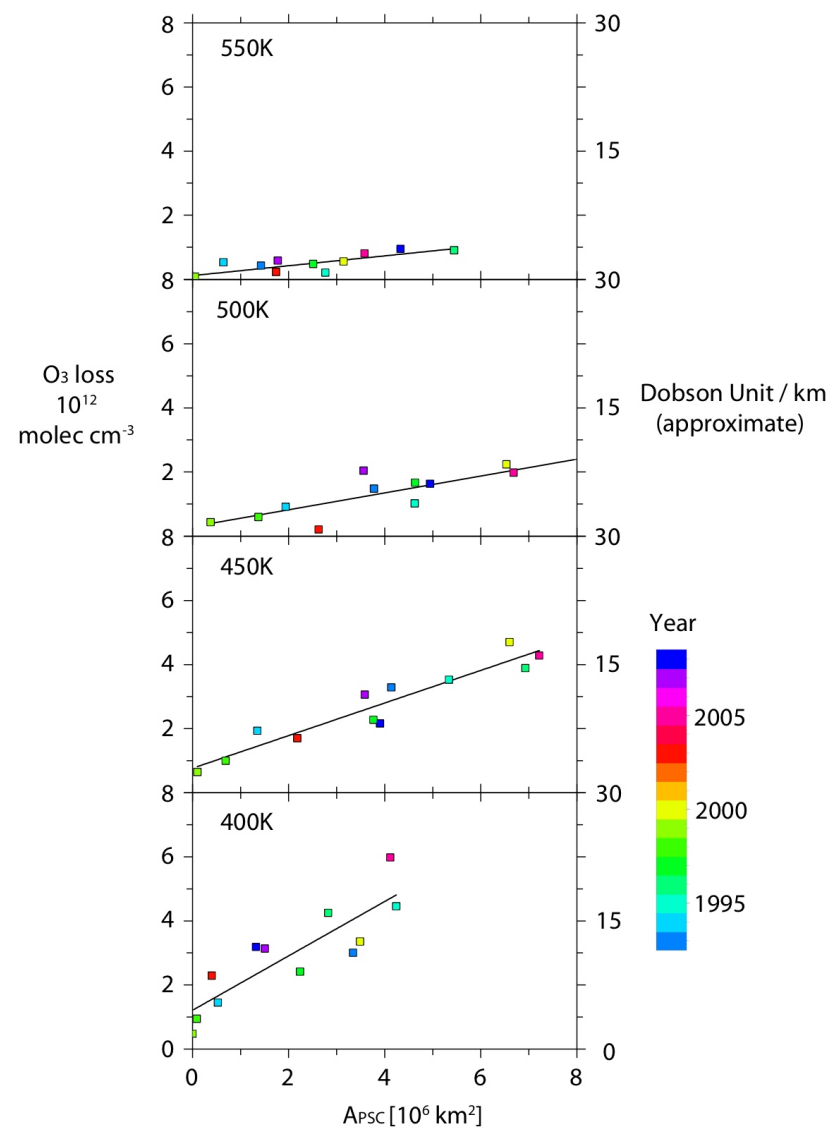

Fig. 3. Integrated ozone loss for individual subsiding surfaces derived with the approach described in Rex et al. (2006) as a function of $A_{\text {PSC }}$ for $1992 / 1993$ to $2008 / 2009$. The potential temperature shown in each panel is the spring equivalent potential temperature which is the value of the subsiding layers at the end of winter. Other details are given in the caption for Fig. 2. We estimate that the absolute uncertainties associated with the ozone loss at 400, 450 and $500 \mathrm{~K}$ are $\pm 0.75 \times 10^{12}$ molec $\mathrm{cm}^{-3}$ and $\pm 0.5 \times 10^{12} \mathrm{molec} \mathrm{cm}^{-3}$ at $550 \mathrm{~K}$ where there is less sensitivity to errors in the diabatic cooling. The relative uncertainty associated with APSC is estimated to be $\pm 20 \%$.

tropic surfaces "descend" over the course of the winter according to the diabatic heating rates calculated in the SLIMCAT model whose validity has been shown by comparisons of modelled and observed long-lived tracers (Feng et al., 2005). The isentropic surface referred to is the one at the end of the winter, and is referred to here as spring equivalent potential temperature $(e \theta)$.) The ozone losses in Fig. 3 are shown in molec $\mathrm{cm}^{-3}$ (not ppm), so that their relative contributions to the column can be seen. The plots for these $e \theta$ levels are generally similar to the column plot of ozone loss vs $V_{\mathrm{PSC}}$, being reasonably linear and compact. The slopes are greatest at $e \theta=400 \mathrm{~K}$ and $450 \mathrm{~K}$ $\left(0.85 \pm 0.16\right.$, and $0.51 \pm 0.055$ molec $\mathrm{cm}^{-3} /$ million $\mathrm{km}^{2}$, respectively: 1 s.d.), with smaller values at $500 \mathrm{~K}$ and 
$550 \mathrm{~K}\left(0.26 \pm 0.057, \quad 0.15 \pm 0.041\right.$ molec $\mathrm{cm}^{-3} /$ million $\mathrm{km}^{2}$, respectively), showing the importance of the lower levels to the integrated column loss. The $550 \mathrm{~K}$ plot has the largest relative scatter. This is partly due to the smaller ozone losses found there and partly due to the poorer data quality (a significant fraction of ozonesondes do not reach that high especially early in winter as the descending layer starts at 600 or $700 \mathrm{~K})$.

$V_{\mathrm{PSC}}$ and APSC in Figs. 2 and 3 are meant as proxies for the geographical extent of conditions favourable for chlorine activation. The values in these plots are derived from meteorological analyses based on a threshold temperature for the existence of such conditions. The particular numerical values in the plots show the results for using the NAT equilibrium temperature $\left(T_{\mathrm{NAT}}\right)$ as threshold. The formation of STS is a gradual process without such a clear threshold. But the efficiency of chlorine activation on STS is a steep function of temperature and the NAT equilibrium temperature is very close to the small range of temperatures at which the chlorine activation on STS becomes efficient on timescales of days or hours. So using $T_{\mathrm{NAT}}$ as the proxy for chemical processing due to heterogeneous reactions is meaningful even though the real process of activation is more complicated and involves different types of droplets or particles in the stratosphere. The composition of large-scale fields of PSCs has been recently investigated using the MIPAS infrared sounder and the CALIPSO/CALIOP lidar measurements (Höpfner et al., 2009; Pitts et al., 2007, 2009). They find that the PSC fields can be described by four main types (ice, NAT-STS mixtures, STS-ICE mixtures, and just STS). The overall evolution of the observed PSCs is similar to that deduced from meteorological analyses. In the Antarctic (their main focus) they find that the PSC occurrences calculated from meteorological analyses are 30-40\% less than their observations. However it is hard to make quantitative comparisons. Pitts et al (2009) use observed $\mathrm{HNO}_{3}$ and $\mathrm{H}_{2} \mathrm{O}$ fields to calculate possible PSC existence while we assume a temporally unvarying concentration profile. In the Antarctic they observe significant amounts of optically thin NAT which are at the threshold limit of their instruments. A closer examination of these issues in the Arctic is needed to see if these findings are also valid there.

The effect of using $T_{\mathrm{NAT}}$ as the temperature threshold for calculating our PSC proxy was investigated by Tilmes et al. (2008). They introduced a PSC proxy based on a temperature threshold for the activation of chlorine on STS and cold background aerosol and investigated the effect of using this PSC formulation on the ozone loss/ $V_{\text {PSC }}$ relation. Significant differences were only found in winters with high sulphate aerosol loading, i.e. 1991/1992 and 1992/1993 following the Mt Pinatubo eruption. For comparison, we have used the temperature dependent cold aerosol formation to calculate APSC (as in Fig. 3, but not shown). No meaningful difference is found except at $e \theta=400 \mathrm{~K}$, where there is a slightly more compact relation with a correspondingly higher $R^{2}$ value.
This is presumably related to the higher amount of background aerosol at these altitudes. This is consistent with the CALIOP analysis in the Antarctic which shows the biggest discrepancy in a $1-2 \mathrm{~km}$ band at altitudes below $15 \mathrm{~km}$ at the beginning of winter (Fig. 14c in Pitts et al., 2009). A similar feature can be seen in the comparison of calculated PSC occurrence using $T_{\mathrm{NAT}}$ with ground-based lidar observations in 1999/2000 Arctic winter (Fig. 2 in Rex et al., 2002). Overall we conclude that $V_{\mathrm{PSC}}$ and $A_{\mathrm{PSC}}$ calculated using NAT existence are good proxies for the existence of PSCs, the activation of chlorine and for threshold conditions for ozone loss.

\section{Idealised case: a single layer}

We now examine the relationship of the ozone loss to the photochemical steps involved in the activation and deactivation of $\mathrm{ClO}_{\mathrm{x}}$ at $50 \mathrm{hPa}$ using the AWI box model. In section 4.1 we discuss the effects of the frequency of occurrence and temperature of the PSCs; while in Sect. 4.2 we investigate the competition between the ozone loss and $\mathrm{ClO}_{\mathrm{x}}$ deactivation chemistry.

\subsection{Activation}

Figure $4 \mathrm{a}$ shows the mixing ratios of the chlorine reservoirs, $\mathrm{ClONO}_{2}$ and $\mathrm{HCl}$, and the activated forms $\mathrm{ClO}_{\mathrm{x}}$ from 1 December to 14 February assuming that PSCs are continuously present. The assumed temperature is $194 \mathrm{~K}$ which is representative of the vortex as a whole. Two phases can be seen: (i) a rapid initial rise in $\mathrm{ClO}_{\mathrm{x}}$ associated with equal decreases in both $\mathrm{HCl}$ and $\mathrm{ClONO}_{2}$; and (ii) a slower continued increase in $\mathrm{ClO}_{\mathrm{x}}$ accompanied by a continued decrease in $\mathrm{HCl}$. By the end of the period, nearly all the available chlorine is in the form of $\mathrm{ClO}_{\mathrm{x}}$. $\mathrm{ClO}_{\mathrm{x}}$ rises initially as a result of the fast heterogeneous reaction between $\mathrm{ClONO}_{2}$ and $\mathrm{HCl}$, with the extent of the initial activation being determined by the amount of $\mathrm{ClONO}_{2}$ initially present (Müller et al., 1994; Santee et al., 2008). The heterogeneous reaction of $\mathrm{ClONO}_{2}+\mathrm{HCl}$ proceeds quicker at lower temperatures, and the main effect of lower temperatures is thus to accelerate the initial activation (Fig. 4b).

If the initial mixing ratio of $\mathrm{HCl}$ is greater than that of $\mathrm{ClONO}_{2}$, further activation depends on the formation of more $\mathrm{ClONO}_{2}$ (e.g., Müller et al., 1994) which depends in turn on the photolysis of $\mathrm{HNO}_{3}$ producing $\mathrm{NO}_{2}$ which reacts with $\mathrm{ClO}$ to form $\mathrm{ClONO}_{2}$. In the presence of PSCs, the $\mathrm{ClONO}_{2}$ reacts rapidly with $\mathrm{HCl}$ to produce more $\mathrm{ClO}_{\mathrm{x}}$. In the Arctic winter the slow step in the overall activation mechanism is the photolysis of $\mathrm{HNO}_{3}$, with a timescale of days to weeks.

$\mathrm{ClONO}_{2}+\mathrm{HCl} \stackrel{\text { het }}{\rightarrow} \mathrm{Cl}_{2}+\mathrm{HNO}_{3}$

$\mathrm{HNO}_{3}+\mathrm{h} v \rightarrow \mathrm{NO}_{2}+\mathrm{OH}$ 


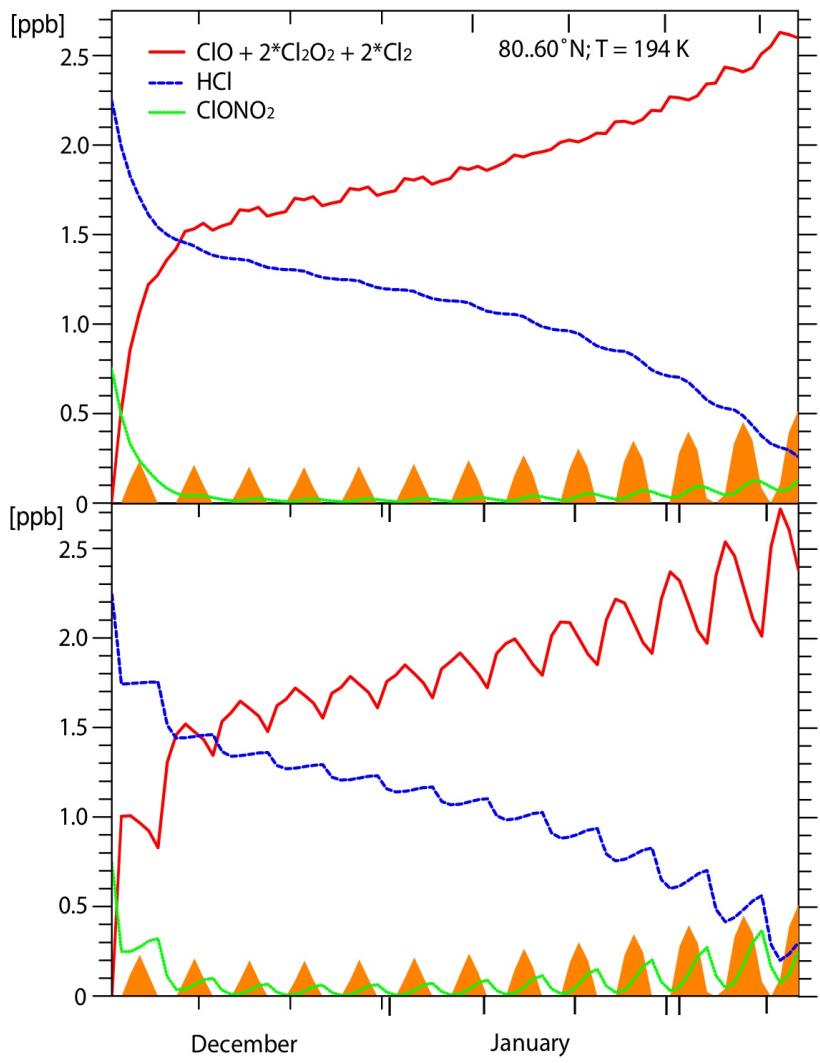

Fig. 4. (a) The evolution of $\left(\mathrm{ClO}_{\mathrm{x}}+2 \mathrm{Cl}_{2}\right), \mathrm{HCl}$ and $\mathrm{ClONO}_{2}$ for an idealised trajectory at a temperature of $194 \mathrm{~K}$ and $50 \mathrm{hPa}$ with continued activation from 1 December to 14 February. The latitude of the trajectory oscillates around $80^{\circ} \mathrm{N}$ with a $20^{\circ}$ amplitude. The orange shading indicates the sunlight exposure experienced by the air parcel. (b) The same for an idealised trajectory at $50 \mathrm{hPa}$ with a one day period of activation at $192 \mathrm{~K}$ every six days from 1 December to 14 February.

$\mathrm{NO}_{2}+\mathrm{ClO}+M \rightarrow \mathrm{ClONO}_{2}+M$.

The slow, continued rise in $\mathrm{ClO}_{\mathrm{x}}$ in Fig. 4 thus depends principally on the photolysis frequency, $J\left(\mathrm{HNO}_{3}\right)$, and this factor is responsible for the acceleration in the activation after mid-winter. The initial activation is also faster if the $\mathrm{ClONO}_{2}: \mathrm{HCl}$ ratio is closer to unity. If significant chlorine activation occurs, Reaction (R3) is sufficiently fast that most of the $\mathrm{NO}_{2}$ produced by the photolysis of $\mathrm{ClONO}_{2}$ reacts back to $\mathrm{ClONO}_{2}$ with a time constant of a few minutes, and so the $\mathrm{ClONO}_{2}$ photolysis can be disregarded in these conditions.

In the real Arctic vortex, the initial activation is patchy depending on the altitudes and regions where the PSCs first form as well as on their extent. Vortex average $\mathrm{ClO}_{\mathrm{x}}$ initially rises slower in reality than in the idealised case, as indicated in Fig. 1. To illustrate this, Fig. 4b shows the same model calculation as in Fig. 4a, except that the PSCs occur episodically (1 day in 6 ) and at temperatures of $192 \mathrm{~K}$. The stabilisa-

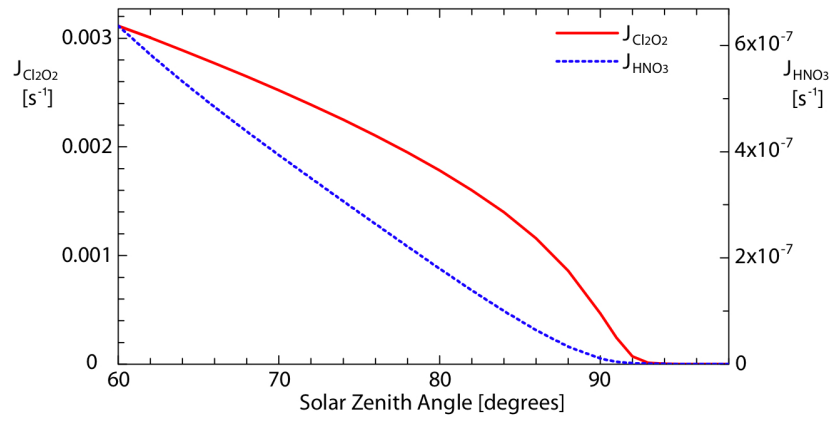

Fig. 5. The photolysis frequencies of $\mathrm{HNO}_{3}$ and $\mathrm{Cl}_{2} \mathrm{O}_{2}$ at $50 \mathrm{hPa}$ in the Arctic vortex as a function of solar zenith angle.

tion of $\mathrm{HCl}$ between PSC exposures is a result of the lack of PSCs. Each of the small rises in $\mathrm{ClO}_{\mathrm{x}}$ results from exposure to PSCs, and the decreases occur during exposure to sunlight (orange). The overall shape is still determined by $J\left(\mathrm{HNO}_{3}\right)$. Further, the initial rapid activation could be responsible for the non-zero intercepts in Figs. 2 and 3, as any small-scale or sub-grid process leading to PSC formation (e.g. mountain waves) could rapidly activate a small but significant amount of air while barely contributing to $V_{\mathrm{PSC}}$.

Overall, our analysis of the chlorine activation shows that activation in Reaction (R1) is fast and that the rate limiting factor for any continued activation is the photolysis of $\mathrm{HNO}_{3}$ to form $\mathrm{NO}_{2}$ in Reaction (R2) and then $\mathrm{ClONO}_{2}$ in Reaction (R3). To first order the photolysis of $\mathrm{HNO}_{3}$ does not vary much from year to year, and so interannual variations in activation depend on the presence of PSCs for activation to occur through Reaction (R1).

\subsection{Deactivation and ozone loss}

There have not been many studies explicitly looking at how the amount of ozone loss depends on the timing and extent of the initial activation. The main ozone loss period starts early in the year as the insolation increases. The instantaneous ozone loss rates have been observed to peak in late January with a gradual reduction thereafter (von der Gathen et al., 1995). The daily ozone loss rate maximises a little later as it is also determined by the length of the day which is increasing in this period. As discussed in Harris et al. (2009), both the ozone loss and the chlorine deactivation are driven by sunlight and so the ozone loss and chlorine deactivation processes accelerate as the insolation increases. The rate limiting step for ozone loss in the Arctic (for a given amount of total inorganic chlorine $\left.\left(\mathrm{ClO}_{\mathrm{x}}\right)\right)$ is:

$\mathrm{Cl}_{2} \mathrm{O}_{2}+h v \rightarrow \mathrm{ClOO}+\mathrm{Cl}$

while in the absence of PSCs, Reactions (R2) and (R3) become the main deactivation mechanism.

Both $\mathrm{HNO}_{3}$ and $\mathrm{Cl}_{2} \mathrm{O}_{2}$ are photolysed in the UV, and the atmospheric photolysis rates of both Reactions (R2) and 


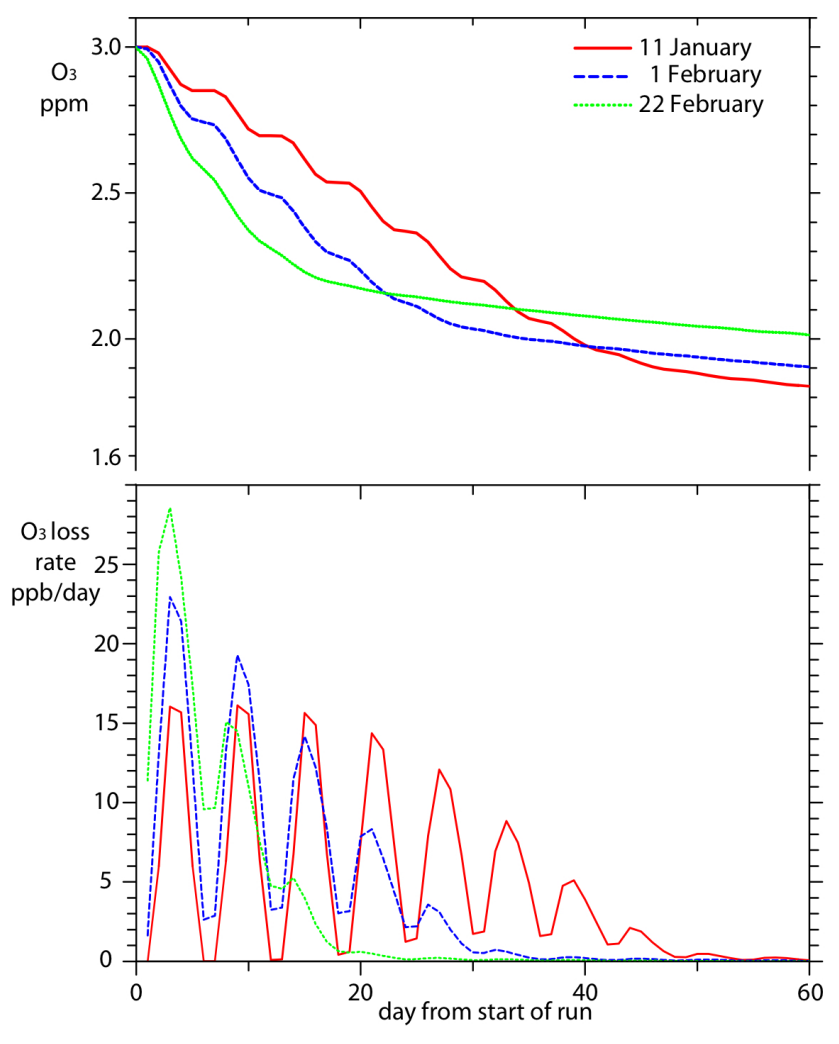

Fig. 6. Ozone mixing ratios calculated for an air parcel with an initial chlorine activation of 3 ppb $\mathrm{ClO}_{\mathrm{x}}$ on 11 January (red), 1 February (blue) and 22 February (green); and (b) the ozone loss rates for the same cases.

(R4) in the Arctic polar lower stratosphere depend mainly on wavelengths longer than $300 \mathrm{~nm}$ as shorter wavelengths are absorbed by stratospheric ozone.

Figure 5 shows these photolysis rates as a function of solar zenith angle. They both increase markedly as the solar zenith angle decreases as winter turns into spring. To first order both the chlorine deactivation rate, which determines the duration of the ozone loss, and the instantaneous ozone loss rate are proportional to the insolation, with both processes having a timescale of several days at $70-75^{\circ} \mathrm{N}$ in January and February. As a result the integrated ozone loss is, to first order, independent of the insolation and the timing of the activation, but is dependent on the original level of activation.

The effect of the timing of activation on the ozone loss rates and on the ozone itself can be seen clearly in Fig. 6. All cases have an initial activation of $3 \mathrm{ppb}$ of $\mathrm{ClO}_{\mathrm{x}}$ with the same hypothetical trajectory used before $(50 \mathrm{hPa}$ centred at $80^{\circ} \mathrm{N}$ with $20^{\circ}$ deviation with a 6 day cycle). The only difference is in the start dates which are set three weeks apart: 11 January (red), 1 February (blue) and 22 February (green). The later the activation, the larger the daily ozone loss, the shorter the period of ozone loss. Despite the large differences in the start dates and the evolutions of the ozone loss rates, the cumulative ozone losses are within $\pm 10 \%$ (1.16 ppm for 11 January 1.10 for 1 February and $0.99 \mathrm{ppm}$ for 22 February).

While this analysis highlights the importance of the two photolysis Reactions (R2) and (R4) in determining ozone loss in the Arctic, other processes do play a limited role. For example, in Fig. 6 a smaller ozone loss is calculated when the 22 February start date is used. This is consistent with the greater sensitivity of the $\mathrm{Cl}_{2} \mathrm{O}_{2}$ photolysis rate to decreasing SZA at high SZA $\left(\sim 90^{\circ}\right)$ and the greater sensitivity of the $\mathrm{HNO}_{3}$ photolysis rate at lower SZA $\left(\sim 70-80^{\circ}\right)$ shown in Fig. 5. Also, the conversion of $\mathrm{HNO}_{3}$ to $\mathrm{NO}_{\mathrm{x}}$ via the alternative channel

$\mathrm{OH}+\mathrm{HNO}_{3} \rightarrow \mathrm{NO}_{3}+\mathrm{H}_{2} \mathrm{O}$

depends on $J\left(\mathrm{HNO}_{3}\right)$ since $\mathrm{HNO}_{3}$ photolysis is the main formation pathway for $\mathrm{OH}$ in polar spring.

In addition, reactions which play an important role in Antarctic ozone loss are less significant in most Arctic winters. The highly temperature-dependent, heterogeneous reactivation of $\mathrm{ClONO}_{2}$ through

$\mathrm{ClONO}_{2}+\mathrm{H}_{2} \mathrm{O} \rightarrow \mathrm{HOCl}+\mathrm{HNO}_{3}$

is unimportant in most Arctic winters.

The sensitivity with respect to the calculated ozone loss with respect to the assumptions on the idealised trajectories was investigated by repeating the model runs shown in Fig. 6 at two fixed latitudes, $65^{\circ} \mathrm{N}$ and $75^{\circ} \mathrm{N}$. The difference in the cumulative ozone losses for the three start dates was $\sim \pm 10 \%$, similar to the result found for the base case trajectory with varying latitudes. However, the ozone loss does depend on latitude: the greatest loss (1.3 ppm) was seen for the case where the trajectory started on 11 January at $75^{\circ} \mathrm{N}$, while the smallest $(0.8 \mathrm{ppm})$ occurred when the trajectory started on 22 January at $65^{\circ} \mathrm{N}$. These variations also illustrate one of the reasons we chose base case trajectories which cover a realistic range of latitudes.

A further important point about the degree of activation is that the ozone loss is close to linear with $\mathrm{ClO}_{\mathrm{x}}$. The blue line in Fig. 7 shows the dependence of the accumulated ozone loss at $500 \mathrm{~K}$ (close to $50 \mathrm{hPa}$, the level of the calculations shown in Fig. 6) on the initial amount of $\mathrm{ClO}_{\mathrm{x}}$. The accumulated ozone losses for 1,2 and $3 \mathrm{ppb} \mathrm{ClO}_{\mathrm{x}}$ at $500 \mathrm{~K}$ are 0.27 , 0.59 and 1.00, respectively, so that there is a small, positive non-linearity in this relationship.

\section{Extending to the 3-D view}

The analysis discussed in section 4 is concerned only with a single layer in the Arctic vortex. In this section we look at some of the greater complexities of the real atmosphere by investigating the effects of a number of the three-dimensional processes which affect ozone loss: (1) dependence of reaction rate coefficients on pressure (altitude); (2) the increasing 


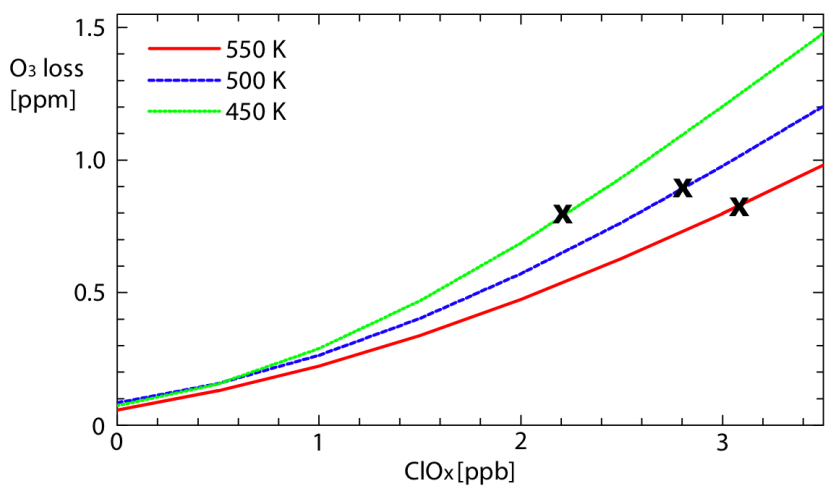

Fig. 7. Integrated ozone loss as a function of initial activation on the $450 \mathrm{~K}$ (green), $500 \mathrm{~K}$ (blue) and $550 \mathrm{~K}$ (red) potential temperature surfaces. The crosses represent the amount of available inorganic chlorine in March 1992 inferred by Schmidt et al. (1994).

$\mathrm{Cl}_{\mathrm{y}}$ with altitude; (3) the vertical redistribution of $\mathrm{NO}_{\mathrm{y}}$ in de/renitrification; (4) the interannual variation of transport.

\subsection{Dependence of reaction rate coefficients on pressure (altitude)}

For fixed $\mathrm{ClO}_{\mathrm{x}}$, the potential for ozone loss depends slightly on pressure, with larger ozone losses calculated at lower potential temperatures as shown in Fig. 7. For an initial $\mathrm{ClO}_{\mathrm{x}}$ of $3 \mathrm{ppb}$, the accumulated ozone losses at 450,500 and $550 \mathrm{~K}$ are $1.2,1.0$ and $0.8 \mathrm{ppm}$. The reasons for the pressure dependence are as follows.

(a) At higher altitudes the $\mathrm{ClO}$ and $\mathrm{BrO}$ concentrations are smaller for the same mixing ratios, as is the overall pressure, thus reducing the rates of the reactions

$\mathrm{ClO}+\mathrm{ClO}+M \rightarrow \mathrm{Cl}_{2} \mathrm{O}_{2}+M$

$\mathrm{ClO}+\mathrm{BrO} \rightarrow \mathrm{Br}+\mathrm{Cl}+\mathrm{O}_{2}$.

(b) At higher altitudes the chlorine deactivation rate is higher, because $\mathrm{NO}_{2}$ production through both $\mathrm{HNO}_{3}$ photolysis and (R5) is faster. An increase of the $\mathrm{HNO}_{3}$ mixing ratio with altitude, not considered in the present model runs, would amplify this effect.

Two possibly counteracting effects at higher altitudes are the faster rate of the reaction

$\mathrm{ClO}+\mathrm{O} \rightarrow \mathrm{Cl}+\mathrm{O}_{2}$

because the $\mathrm{O}$ concentration increases with altitude; and the faster photolysis of $\mathrm{Cl}_{2} \mathrm{O}_{2}$ (Reaction R4). However these are small compared to points (a) and (b).

\subsection{Available chlorine}

The amount of available chlorine increases rapidly with altitude in the Arctic vortex (Schmidt et al., 1994). As a result, more chlorine is activated for a given PSC exposure at higher altitudes. The black crosses in Fig. 7 indicate the values of $\mathrm{Cl}_{\mathrm{y}}$ measured toward the end of the 1991/1992 winter (Schmidt et al., 1994). Taking these as representative upper limits for the amount of $\mathrm{ClO}_{\mathrm{x}}$ initially available shows that as altitude increases the additional $\mathrm{Cl}_{\mathrm{y}}$ offsets the decreasing efficiency of the ozone loss processes. The combined effect is to limit the importance of any interannual variations of PSC altitudes on the integrated ozone loss.

\subsection{Vertical Redistribution of $\mathrm{NO}_{\mathrm{y}}$}

The vertical redistribution of $\mathrm{NO}_{\mathrm{y}}$ through denitrification at higher altitudes and renitrification at lower altitudes has been widely cited as having a major impact on the accumulated ozone loss as the removal of $\mathrm{NO}_{\mathrm{y}}$ limits the deactivation of $\mathrm{ClO}_{\mathrm{x}}$ through (R3). Significant denitrification in the Arctic only occurs in a few winters (1994/1995 (Sugita et al., 1998); 1995/1996 (Rex et al., 1997); 1999/2000 (e.g., Popp et al., 2001) and 2004/2005 (Kleinböhl et al., 2005)), which are the winters with the larger ozone losses in the top right of Fig. 2. Denitrification in the majority of winters is negligible, even non-existent. When large-scale denitrification does occur, the enhanced ozone loss in the denitrified layer tends to be offset by reduced ozone loss in a lower, renitrified layer (e.g. Rex et al., 1997). The magnitude of this effect is investigated here by assuming a denitrification at $550 \mathrm{~K}$ of $5 \mathrm{ppb}$ (Fig. 8a) and a concurrent renitrification of $5 \mathrm{ppb}$ at $450 \mathrm{~K}$ (Fig. 8b), similar to those reported by Popp et al. (2001). For a given $\mathrm{ClO}_{\mathrm{x}}$, there is a greater sensitivity of ozone loss to changes in $\mathrm{NO}_{\mathrm{y}}$ at $450 \mathrm{~K}$ than at higher altitudes (though note that the cases shown are for similar changes in mixing ratio, not concentration). However at this level, the $\mathrm{Cl}_{\mathrm{y}}$ and $\mathrm{ClO}_{\mathrm{x}}$ are lower and so the overall effect of this hypothetical de/renitrification on the vertically integrated ozone loss is limited. Interestingly (but not conclusively) if one looks at particular years in Fig. 3, one can see indications of both denitrification and renitrification. For example in 1999/2000, a year of extensive ozone loss and well observed denitrification, Fig 3 b shows higher than "expected" ozone loss at $e \theta=450 \mathrm{~K}$ and less than "expected" at $400 \mathrm{~K}$, consistent with the altitudes of the observed denitrification/renitrification (Popp et al., 2001).

\subsection{Interannual variations in transport}

A further process which could affect the chemical recovery is any in-mixing of air with a different chemical composition from outside the vortex. Previous work indicates that this is not a significant influence on ozone loss in the Arctic vortex (Newman and Pyle, 2003) despite the identification of individual events (e.g., Pyle et al., 1994).

\section{Discussion and summary}

We have updated and extended the previous studies reporting the empirical relation between accumulated ozone loss and 

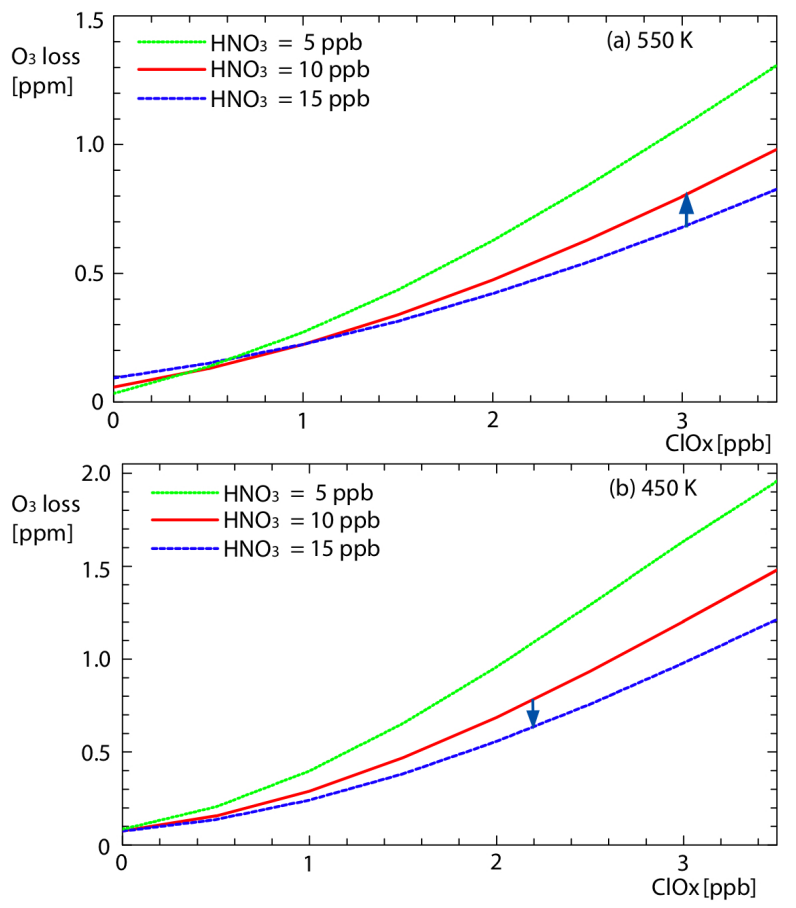

Fig. 8. The integrated ozone loss as a function of initial activation on the (a) $550 \mathrm{~K}$ and (b) $450 \mathrm{~K}$ potential temperature surfaces. The green lines show the effect of $\mathrm{HNO}_{3}=5 \mathrm{ppb}$, the red lines for $\mathrm{HNO}_{3}=10 \mathrm{ppb}$ and the blue lines for $\mathrm{HNO}_{3}=15 \mathrm{ppb}$. The arrows indicate the effect of a dentrification of $5 \mathrm{ppb}$ at $550 \mathrm{~K}$ in (a) and a renitrification of $5 \mathrm{ppb}$ at $450 \mathrm{~K}$ in (b).

potential PSC volume in the Arctic vortex (Rex et al., 2004, 2006; Tilmes et al., 2004) using the ERA-Interim reanalyses

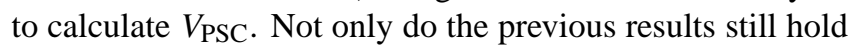
with additional winters and the self-consistent meteorological data set, but they are also shown to hold on individual potential temperature surfaces albeit with greater scatter. At $e \theta=400 \mathrm{~K}$, the relationship is found to be slightly more significant when cold aerosol activation is assumed in the place of NAT. This is consistent with the larger amounts of background aerosol at $400 \mathrm{~K}$ than at higher altitudes. At higher potential temperatures, the correlation with PSC areas deduced from NAT existence is better. This finding implies a smaller sensitivity of ozone loss to stratospheric aerosol loading than that found by Tilmes et al. (2008) in their assessment of the deliberate maintenance of an enhanced stratospheric aerosol layer as a geo-engineering response to climate change.

The compactness and linearity of the empirical results are interpreted using a photochemical box model with standard photochemistry and idealised trajectories. The aim is to identify the important mechanisms, not to reproduce the losses from winter to winter. (More complete reconstructions have been successfully reported elsewhere using a 3-D CTM and analysed meteorological fields (Chipperfield et al., 2005; Tilmes, 2007).) We show that the principal timescale for the extensive activation of chlorine is not the fast reaction of $\mathrm{ClONO}_{2}$ and $\mathrm{HCl}$ on NAT particles but the re-supply of $\mathrm{ClONO}_{2}$ with photolysis of $\mathrm{HNO}_{3}$ as the rate determining step. As a result, extensive activation in the Arctic vortex takes place with a timescale of days to weeks, and the overall activation depends on the continued (though not necessarily the continuous) presence of PSCs. The use of $V_{\mathrm{PSC}}$ is thus a sensible proxy for the activation process.

The extent of ozone loss in any particular winter is found to depend most strongly on the degree of activation and not so much on its timing or vertical distribution. This somewhat surprising finding occurs as a result of a number of offsetting factors. For any given air mass, there is the almost cancelling competition between ozone loss and chlorine deactivation, both of which rely on the photolysis in the near UV and so accelerate as the Sun becomes higher in the sky in early spring. In the vertical, the effect of the decreasing number density with altitude is offset by the increasing $\mathrm{Cl}_{\mathrm{y}}$ mixing ratios, and in the few winters where denitrification occurs the increased ozone loss at the denitrified altitudes is offset by the decreased ozone loss at the lower altitudes where renitrification takes place. The baroclinicity of the vortex affects the degree of denitrification (Mann et al., 2003): this would affect our conclusions about denitrification if the cold region were sufficiently deep that the renitrification occurred below the region of ozone loss. However this is very rare in the Arctic and has probably not occurred even in the years of extensive denitrification.

These findings raise a number of interesting possibilities for the development of simple parameterisations of stratospheric Arctic (or even polar) ozone loss in coupled chemistry climate models (CCMs), a step beyond the use of simple models to investigate future sensitivities (Knudsen et al., 2004; Tilmes et al., 2008). For example, the relationship shown in Fig. 2, which is derived in a period of high and nearly constant $\mathrm{Cl}_{\mathrm{y}}$, could be scaled by the levels of $\mathrm{Cl}_{\mathrm{y}}$ calculated in the CCMs. As $\mathrm{Cl}_{\mathrm{y}}$ decreases so will ozone loss - but the effect of any changes in the occurrence of PSCs resulting from climate change would be allowed for. A slightly more sophisticated and intellectually more satisfying approach based on processes would be to develop a simplified photochemical model based around the main features described above, namely photolysis of nitric acid and $\mathrm{Cl}_{2} \mathrm{O}_{2}$, an activation involving $\mathrm{ClONO}_{2}$ on PSCs, and the initial levels of $\mathrm{Cl}_{\mathrm{y}}$. The success of either of these schemes would depend on good representations of PSCs and denitrification, which implies a need for continued improvements to the dynamical schemes used in CCMs which determine temperature and vortex characteristics, rather than to the photochemical schemes. These comments only apply to polar ozone loss, because of the unique nature of the stratosphere over the poles. Additionally this work underlines the value of more analysis of the existing models to see where simplifying assumptions are justified and where parameterisations might be made. 
Acknowledgements. This work was supported by the EU Integrated Project SCOUT-O3 (505390-GOCE-CT-2004) and by the BMBF DYCHO project (FKZ07ATC08). NRPH thanks NERC for an Advanced Research Fellowship. We thank the many ozonesonde personnel who have launched the ozonesondes used in this analysis. Michelle Santee and Peter Bernath provided useful and helpful advice. Meteorological data were provided by ECMWF and FU-Berlin. The ACE mission is supported primarily by the Canadian Space Agency. EOS Aura MLS is supported by NASA.

Edited by: M. Dameris

\section{References}

Anderson, J. G., Brune, W. H., and Proffitt, M. H.: Ozone destruction by chlorine radicals within the Antarctic vortex: the spatial and temporal evolution of $\mathrm{C} 1 \mathrm{O}-\mathrm{O}_{3}$ anticorrelation based on in situ ER-2 data, J. Geophys. Res., 94(D9), 11465-11479, 1989.

Austin, J., Shindell, D., Beagley, S. R., Brühl, C., Dameris, M., Manzini, E., Nagashima, T., Newman, P., Pawson, S., Pitari, G., Rozanov, E., Schnadt, C., and Shepherd, T. G.: Uncertainties and assessments of chemistry-climate models of the stratosphere, Atmos. Chem. Phys., 3, 1-27, doi:10.5194/acp-3-1-2003, 2003.

Bodeker, G. E., Shiona, H., and Eskes, H.: Indicators of Antarctic ozone depletion, Atmos. Chem. Phys., 5, 2603-2615, doi:10.5194/acp-5-2603-2005, 2005.

Burkholder, J. B., Orlando, J. J., and Howard, C. J.: Ultraviolet absorption cross sections of $\mathrm{Cl}_{2} \mathrm{O}_{2}$ between 210 and $410 \mathrm{~nm}, \mathrm{~J}$. Phys. Chem., 94, 687-695, 1990.

Carslaw, K. S., Luo, B., and Peter, T.: An analytic expression for the composition of aqueous $\mathrm{HNO}_{3}-\mathrm{H}_{2} \mathrm{SO}_{4}$ stratospheric aerosols including gas phase removal of $\mathrm{HNO}_{3}$, Geophys. Res. Lett., 22, 1877-1880, 1995.

Chen, H.-Y., Lien, C.-Y., Lin, W.-Y., Lee, Y. T., and Lin, J. J.: UV absorption cross sections of $\mathrm{ClOOCl}$ are consistent with ozone degradation models, Science, 324, 781, doi:10.1126/science.1171305, 2009.

Chipperfield, M. P., Feng, W., and Rex, M.: Arctic ozone loss and climate sensitivity: Updated three-dimensional model study, Geophys. Res. Lett., 32, L11813, doi:10.1029/2005GL022674, 2005.

Damian, V., Sandu, A., Damian, M., Potra, F., and Carmichael, G. R.: The kinetic preprocessor KPP - a software environment for solving chemical kinetics, Comp. and Chem. Eng., 26, 15671579, 2000.

De Zafra, R. L., Jaramillo, M., Parrish, A., Solomon, P., Connor, B., and Barrett, J.: High concentrations of chlorine monoxide at low altitudes in the Antarctic spring stratosphere: diurnal variation, Nature, 328, 408-411, 1987.

Dobson, G. M. B.: Forty years' research on atmospheric ozone at Oxford: a history, Appl. Opt., 7, 3, 387-405, 1968.

Drdla, K., Gandrud, B. W., Baumgardner, D., Wilson, J. C., Bui, T. P., Hurst, D., Schauffler, S. M., Jost, H., Greenblatt, J. B., and Webster, C. R.: Evidence for the widespread presence of liquidphase particles during the 1999-2000 Arctic winter, J. Geophys. Res., 107, 8318, doi:10.1029/2001JD001127, 2002.

Eyring, V., Harris, N. R. P., Rex, M., Shepherd, T. G., Fahey, D. W., Amanatidis, G. T., Austin, J., Chipperfield, M. P., Dameris, M., Forster, P., Gettelman, A., Graf, H. F., Nagashima, T., Newman,
P. A., Prather, M. J., Pyle, J. A., Salawitch, R. J., Santer, B. D., and Waugh, D. W.: A strategy for process-oriented validation of coupled chemistry-climate models, Bull. Am. Meteor. Soc., 86, 1117-1133, 2005.

Eyring, V., Waugh, D. W., Bodeker, G. E., Cordero, E., Akiyoshi, H., Austin, J., Beagley, S. R., Boville, B. A., Braesicke, P., Brühl, C., Butchart, N., Chipperfield, M. P., Dameris, M., Deckert, R., Deushi, M., Frith, S. M., Garcia, R. R., Gettelman, A., Giorgetta, M. A., Kinnison, D. E., Mancini, E., Manzini, E., Marsh, D. R., Matthes, S., Nagashima, T., Newman, P. A., Nielsen, J. E., Pawson, S., Pitari, G., Plummer, D. A., Rozanov, E., Schraner, M., Scinocca, J. F., Semeniuk, K., Shepherd, T. G., Shibata, K., Steil, B., Stolarski, R. S., Tian, W., and Yoshiki, M.: Multimodel projections of stratospheric ozone in the 21st century, J. Geophys. Res., 112, D16303, doi:10.1029/2006JD008332, 2007.

Farman, J. C., Gardiner, B. G., and Shanklin, J. D.: Large losses of total ozone in Antarctica reveal seasonal $\mathrm{ClO}_{\mathrm{x}} / \mathrm{NO}_{\mathrm{x}}$ interaction, Nature, 315, 207-210, 1985.

Feng, W., Chipperfield, M. P., Davies, S., Sen, B., Toon, G., Blavier, J. F., Webster, C. R., Volk, C. M., Ulanovsky, A., Ravegnani, F., von der Gathen, P., Jost, H., Richard, E. C., and Claude, H., Three-dimensional model study of the Arctic ozone loss in 2002/2003 and comparison with 1999/2000 and 2003/2004, Atmos. Chem. Phys., 5, 139-152, doi:10.5194/acp-5-139-2005, 2005.

Hanson, D., and Mauersberger, K.: Laboratory studies of the nitric acid trihydrate: implications for the south polar stratosphere. Geophys. Res. Lett. 15, 855-858, 1988.

Harris, N. R. P., Kyrö, E., Staehelin, J., Brunner, D., Andersen, S.B., Godin-Beekmann, S., Dhomse, S., Hadjinicolaou, P., Hansen, G., Isaksen, I., Jrrar, A., Karpetchko, A., Kivi, R., Knudsen, B., Krizan, P., Lastovicka, J., Maeder, J., Orsolini, Y., Pyle, J. A., Rex, M., Vanicek, K., Weber, M., Wohltmann, I., Zanis, P., and Zerefos, C.: Ozone trends at northern mid- and high latitudes - a European perspective, Ann. Geophys., 26, 1207-1220, doi:10.5194/angeo-26-1207-2008, 2008.

Harris, N. R. P., Lehmann, R., Rex, M., and von der Gathen, P.: Understanding the relation between Arctic ozone loss and the volume of polar stratospheric clouds, Int. J. Remote Sens., 30, 15, 4065-4070, 2009.

Höpfner, M., Pitts, M. C., and Poole, L. R.: Comparison between CALIPSO and MIPAS observations of polar stratospheric clouds, J. Geophys. Res., 114, D00H05, doi:10.1029/2009JD012114, 2009.

Hoppel, K., Bevilacqua, R. M., Allen, D. R., Nedoluha, G., and Randall, C. E., POAM III observations of the anomalous 2002 Antarctic ozone hole, Geophys. Res. Lett., 30(7), 1394, doi:10.1029/2003GL016899, 2003.

Jackson, D. R. and Orsolini, Y. J.: Estimation of Arctic ozone loss in winter 2004/2005 based on assimilation of EOS MLS and SBUV/2 observations, Q. J. R. Meteorol. Soc., 134: 1833-1841, DOI: 10.1002/qj.316, 2008.

Kleinböhl, A., Bremer, H., Küllmann, H., Kuttippurath, J., Browell, E. V., Canty, T., Salawitch, R. J., Toon, G. C., and Notholt, J.: Denitrification in the Arctic mid-winter 2004/2005 observed by airborne submillimeter radiometry, Geophys. Res. Lett., 32(19), L19811, doi:10.1029/2005GL023408, 2005.

Knudsen, B. M., Harris, N. R. P., Andersen, S. B., Christiansen, B., Larsen, N., Rex, M., and Naujokat, B.: Extrapolating fu- 
ture Arctic ozone losses, Atmos. Chem. Phys., 4, 1849-1856, doi:10.5194/acp-4-1849-2004, 2004.

Mann, G. W., Davies, S., Carslaw, K. S., and Chipperfield, M. P.: Factors controlling Arctic denitrification in cold winters of the 1990s, Atmos. Chem. Phys., 3, 403-416, doi:10.5194/acp-3403-2003, 2003.

Müller, R., Peter, Th., Crutzen, P. J., Oelhaf, H., Adrian, G. P., von. Clarmann, Th., Wegner, A., Schmidt, U., and Lary, D.: Chlorine chemistry and the potential for ozone depletion in the arctic stratosphere in the winter of 1991/1992, Geophys. Res. Lett., 21, 1427-1430, 1994.

Murray, F. W.: On the computation of saturation vapor pressure, J. Appl. Meteor., 6, 203-204, 1967.

Newman, P. A., and Pyle, J.A. (Lead Authors), Austin, J., Braathen, G.O., Canziani, P. O., Carslaw, K. S., de F. Forster, P. M., GodinBeekmann, S., Knudsen, B. M., Kreher, K., Nakane, H., Pawson, S., Ramaswamy, V., Rex, M., Salawitch, R. J., D.T. Shindell, D. T., Tabazadeh, A., and Toohey, D. W.: Polar Stratospheric Ozone: Past and Future in Scientific Assessment of Ozone Depletion: 2002, Global Ozone Research and Monitoring Project - Report No. 47, World Meteorological Organization, Geneva, Switzerland, 2003.

Newman, P. A., and Rex, M. (Lead Authors), Canziani, P. O., Carslaw, K. S., Drdla, K., Godin-Beekmann, S., Golden D. M., Jackman, C. H., Kreher, K., Langematz, U., Müller, R., Nakane, H., Orsolini, Y. J., Salawitch, R. J., Santee, M. L., von Hobe, M., and Yoden, S.: Chapter 3 - Polar Ozone: Past and Present in Scientific Assessment of Ozone Depletion: 2006, Global Ozone Research and Monitoring Project - Report No. 50, World Meteorological Organization, Geneva, Switzerland, 2007.

Papanastasiou, D. K., Papadimitriou, V. C., Fahey, D. W., and Burkholder, J. B.: UV absorption spectrum of the $\mathrm{ClO}$ dimer $\left(\mathrm{Cl}_{2} \mathrm{O}_{2}\right)$ between 200 and $420 \mathrm{~nm}$, J. Phys. Chem. A., 113(49), 13711-13726, doi:10.1021/jp9065345, 2009.

Pitts, M. C., Thomason, L. W., Poole, L. R., and Winker, D. M.: Characterization of polar stratospheric clouds with spaceborne lidar: CALIPSO and the 2006 Antarctic season, Atmos. Chem. Phys., 7, 5207-5228, doi:10.5194/acp-7-5207-2007, 2007.

Pitts, M. C., Poole, L. R., and Thomason, L. W.: CALIPSO polar stratospheric cloud observations: second-generation detection algorithm and composition discrimination, Atmos. Chem. Phys., 9, 7577-7589, doi:10.5194/acp-9-7577-2009, 2009.

Popp, P. J., Northway, M. J., Holecek, J. C., Gao, R. S., Fahey, D. W., Elkins, J. W., Hurst, D. F., Romashkin, P. A., Toon, G. C., Sen, B., Schauffier, S. M., Salawitch, R. J., Webster, C.R., Herman, R. L., Jost, H., Bui, T. P., Newman, P. A., and Lait, L. R.: Severe and extensive denitrification in the 1999-2000 Arctic winter stratosphere, Geophys. Res. Lett., 28, 2875-2878, 2001.

Rex, M., Harris, N. R. P., von der Gathen, P., Lehmann, R., Braathen, G. O., Reimer, E., Beck, A., Chipperfield, M. P., Alfier, R., Allaart, M., O'Connor, F., Dier, H., Dorokhov, V., Fast, H., Gil, M., Kyro, E., Litynska, Z., Mikkelsen, I. S., Molyneux, M. G., Nakane, H., Notholt, J., Rummukainen, M., Viatte, P., and Wenger, J.: Prolonged stratospheric ozone loss in the 1995-96 Arctic winter, Nature, 389, 835-838, 1997

Rex, M., von der Gathen, P., Braathen, G. O., Harris, N. R. P., Reimer, E., Beck, A., Alfier, R., Krüger-Carstensen, R., Chipperfield, M., De Backer, H., Balis, D., O’Connor, F., Dier, H., Dorokhov, V., Fast, H., Gamma, A., Gil, M., Kyro, E., Lityn- ska, Z., Mikkelsen, I. S., Molyneux, M., Murphy, G., Reid, S. J. Rummukainen, M., and Zerefos, C.: Chemical Ozone Loss in the Arctic Winter 1994/1995 as Determined by the Match Technique, J. Atmos. Chem., 32, 35-39, 1999.

Rex, M., Salawitch, R. J., Harris, N. R. P., von der Gathen, P., Braathen, G. O., Schulz, A., Deckelmann, H., Chipperfield, M. P., Sinnhuber, B.-M., Reimer, E., Alfier, R., Bevilacqua, R., Hoppel, K., Fromm, M., Lumpe, J., Kuellmann, H., Kleinbohl, A., Bremer, H., von Konig, M., Kunzi, K., Toohey, D., Vomel, H., Richard, E., Aikin, K., Jost, H., Greenblatt, J. B., Loewenstein, M., Podolske, J. R., Webster, C. R., Flesch, G. J., Scott, D. C., Herman, R. L., Elkins, J. W., Ray, E. A., Moore, F. L., Hurst, D. F., Romashkin, P., Toon, G. C., Sen, B., Margitan, J. J., Wennberg, P., Neuber, R., Allart, M., Bojkov, B. R., Claude, H., Davies, J., Davies, W., De Backer, H., Dier, H., Dorokhov, V., Fast, H., Kondo, Y., Kyro, E., Litynska, Z., Mikkelsen, I. S., Molyneux, M. J., Moran, E., Nagai, T., Nakane, H., Parrondo, C., Ravegnani, F., Skrivankova, P., Viatte, P., and Yushkov, V.: Chemical loss of Arctic ozone in winter 1999/2000, J. Geophys. Res., 107(D20), 8276, doi:10.1029/2001JD000533, 2002.

Rex, M., Salawitch, R. J., von der Gathen, P., Harris, N. R. P., Chipperfield, M. P., and Naujokat, B.: Arctic ozone loss and climate change, Geophys. Res. Lett., 31, LO4116, doi:10.1029/2003GL018844, 2004.

Rex, M, Salawitch, R. J., Deckelmann, H., von der Gathen, P., Harris, N. R. P., Chipperfield, M. P., Naujokat, B., Reimer, E., Allaart, M., Andersen, S. B., Bevilacqua, R., Braathen, G. O., Claude, H., Davies, J., De Backer, H., Dier, H., Dorokov, V., Fast, H., Gerding, M., Godin-Beekmann, S., Hoppel, K., Johnson, B., Kyrö, E., Litynska, Z., Moore, D., Nakane, H., Parrondo, M. C., Risley, A. D., Skrivankova, P., Stübi, R., Viatte, P., Yushkov, V., and Zerefos, C.: Arctic winter 2005: Implications for stratospheric ozone loss and climate change, Geophys. Res. Lett., 33, L23808, doi:10.1029/2006GL026731, 2006.

Ricaud, P., Lefèvre, F., Berthet, G., Murtagh, D., Llewellyn, E. J., Mégie, G., Kyrölä, E., Leppelmeier, G. W., Auvinen, H., Boonne, C., Brohede, S., Degenstein, D. A., de La Noë, J., Dupuy, E., El Amraoui, L., Eriksson, P., Evans, W. F. J., Frisk, U., Gattinger, R. L., Girod, F., Haley, C. S., Hassinen, S., Hauchecorne, A., Jimenez, C., Kyrö, E., Lautié, N., Le Flochmoën, E., Lloyd, N. D., McConnell, J. C., McDade, I. C., Nordh, L., Olberg, M., Pazmino, A., Petelina, S. V., Sandqvist, A., Seppälä, A., Sioris, C. E., Solheim, B. H.., Stegman, J., Strong, K., Taalas, P., Urban, J., von Savigny, C., von Scheele, F., and Witt, G., Polar vortex evolution during the 2002 Antarctic major warming as observed by the Odin satellite, J. Geophys. Res., 110, D05302, doi:10.1029/2004JD005018.

Sander, S. P., Finlayson-Pitts, B. J, Friedl, R. R., Golden, D. M., Huie, R. E.., Keller-Rudek, H., Kolb, C. E., Kurylo, M. J., Molina, M. J., Moortgat, G. K., Orkin, V. L., Ravishankara, A. R., and Wine, P. H.: Chemical kinetics and photochemical data for use in atmospheric studies, evaluation number 15, JPL Publication 06-2, Jet Propulsion Laboratory, Pasadena, USA, 2006.

Santee, M. L., MacKenzie, I. A., Manney, G. L., Chipperfield, M. P., Bernath, P. F., Walker, K. A., Boone, C. D., Froidevaux, L., Livesey, N. J., and Waters, J. W.: A study of stratospheric chlorine partitioning based on new satellite measurements and modeling, J. Geophys. Res., 113, D12307, doi:10.1029/2007JD009057, 2008. 
Schmidt, U., Bauer, R., Engel, A., Borchers, R., and Lee, J.: The variation of available chlorine $\mathrm{Cl}_{\mathrm{y}}$ in the arctic polar vortex during EASOE, Geophys. Res. Lett., 21, 1215-1218, 1994.

Schulz, A., Rex, M, Harris, N. R. P., Braathen, G. O., Reimer, E., Alfier, R., Kilbane-Dawe, I., Eckermann, S., Allaart, M., Alpers, M., Bojkov, B., Cisneros, J., Claude, H., Cuevas, E., Davies, J., De Backer, H., Dier, H., Dorokhov, V., Fast, H., Godin, S., Johnson, B., Kondo, Y., Kosmidis, E., Kyro, E., Litynska, Z., Mikkelsen, I. S., Molyneux, M., Murphy, G., Nakane, H., Connor, F. O., Parrondo, C., Schmidlin, F. J., Skrivankova, P., Varotsos, C., Vialle, C., Viatte, P., Yushkov, V., Zerefos, C., and von der Gathen, P.: Arctic ozone loss in threshold conditions: Match observations in 1997/1998 and 1998/1999, J. Geophys. Res., 106, 7495-7503, 2001.

Simmons, A. J., Uppala, S. M., Dee, D., and Kobayashi, S.: ERAInterim: New ECMWF reanalysis products from 1989 onwards, ECMWF News Lett., 110, 25-35, 2006.

Solomon, P. M., Connor, B., de Zafra, R. L.., Parrish, A., Barrett, J., and Jaramillo, M.: High concentrations of chlorine monoxide at low altitudes in the Antarctic spring stratosphere: secular variation, Nature, 328, 411-413, 1987.

SPARC CCMVal, SPARC CCMVal Report on the Evaluation of Chemistry-Climate Models, edited by: Eyring, V., Shepherd, T. G., Waugh, D. W., SPARC Report No. 5, WCRP132, WMO/TD-No. 1526, http://www.atmosp.physics.utoronto. ca/SPARC, 2010.
Sugita, T., Kondo, Y., Nakajima, H., Schmidt, U, Engel, A., Oelhaf, H., Wetzel, G., Koike, M., and Newman, P. A.: Denitrification observed inside the Arctic vortex in February 1995, J. Geophys. Res., 103, 16221-16223, 1998.

Tilmes, S., Müller, R., Grooß, J.-U., and Russell III, J. M.: Ozone loss and chlorine activation in the Arctic winters 1991-2003 derived with the tracer-tracer correlations, Atmos. Chem. Phys., 4, 2181-2213, doi:10.5194/acp-4-2181-2004, 2004.

Tilmes, S., Kinnison, D. E., Garcia, R. R., Müller, R., Sassi, F., Marsh, D. R., and Boville, B. A.: Evaluation of heterogeneous processes in the polar lower stratosphere in the Whole Atmosphere Community Climate Model, J. Geophys. Res., 112, D24301, doi:10.1029/2006JD008334, 2007.

Tilmes, S. and Müller, R.: The sensitivity of polar ozone depletion to proposed geoengineering schemes, Science, 320, 1201, doi:10.1126/science.1153966, 2008.

von der Gathen, P., Rex, M., Harris, N. R. P., Lucic, D., Knudsen, B., Braathen, G. O., de Backer, H., Fabian, R., Fast, H., Gil, M., Kyro, E., Mikkelsen, I. S., Rummukainen, M., Staehelin, J., and Varotsos, C.: Chemical depletion of ozone observed in the Arctic Vortex during the 1991/1992 winter, Nature, 375, 131134, 1995.

von Hobe, M., Stroh, F., Beckers, H., Benter, T., and Willner, H.: The UV/Vis absorption spectrum of matrix-isolated dichlorine peroxide, ClOOCl, Phys. Chem. Chem. Phys., 11, 1571-1580, 2009. 